\title{
Chronic administration of theophylline to rats induces a post-insulin binding defect in adipocyte glucose transport
}

\author{
A. Green \\ Department of Internal Medicine, University of Texas Medical Branch, Galveston, Texas, USA
}

\begin{abstract}
Summary. To determine whether adenosine is involved in long-term regulation of glucose transport in adipose tissue, we have investigated effects of administration of an adenosine receptor antagonist (theophylline) on adipocyte glucose transport. Rats were injected with theophylline $(30 \mathrm{mg} / \mathrm{kg}$, dissolved in $0.9 \% \mathrm{NaCl}$ ) daily for 7 days. Controls were injected with saline. The rats were then killed, and epididymal adipocytes were isolated. Insulin-stimulated glucose transport rates were decreased by about $25 \%-30 \%$ in the cells from theophylline-treated rats at all insulin concentrations tested. The halfmaximally effective concentration of insulin was not altered $(6.5 \pm 0.5$ and $6.7 \pm 0.5 \mathrm{mU} / 1$ in control and treated cells respectively), suggesting a post-insulin binding defect. This was
\end{abstract}

confirmed by the finding that ${ }^{125} \mathrm{I}$-insulin binding to the cells was not altered. Adenosine receptor number and affinity (measured on detergent-solubilized adipocyte extracts using ${ }^{125}$ I-hydroxyphenylisopropyl adenosine) was also not changed by theophylline treatment. We conclude that theophylline administration causes decreased glucose transport rates in rat adipocytes at a post-insulin binding level. Thus, chronic adenosine receptor blockade impairs adipocyte glucose transport, suggesting that adenosine is involved in longterm regulation of glucose metabolism in adipose tissue.

Key words: Methyl xanthines, theophylline, glucose transport, adenosine, adipocyte.
The methyl xanthines (theophylline, caffeine, etc.) have many effects in vitro. However, it is now believed that most, if not all, of the effects of methyl xanthines observed in vivo are due to antagonism of cell-surface adenosine receptors [1,2]. Adenosine is present in most mammalian tissues [3] and has been implicated as an important endogenous regulator of the actions of several hormones [3, 4]. Of particular interest are the findings that adenosine is released by isolated adipocytes $[5,6]$ and can increase the sensitivity of these cells to the actions of insulin on glucose transport $[7,8]$ and oxidation [9]. Adenosine has also been proposed to be an important regulator of lipolyis, both in rat [10] and human [11] adipose tissue.

In addition to the acute in vitro effects of adenosine on insulin sensitivity described above, it has been proposed that chronic alterations in adenosine or adenosine receptor concentration may be involved in the altered insulin sensitivities associated with metabolic states such as starvation, adrenalectomy, obesity and Type 2 (non-insulin-dependent) diabetes [12]. To address specifically the involvement of adenosine in chronic regulation of insulin action, we have investigated the effect of adenosine receptor blockade with theophylline on adipocyte glucose transport.

\section{Materials and methods}

\section{Chemicals}

Porcine insulin was generously given by Dr. M. Root of Eli Lilly (Indianapolis, Ind, USA). Bovine serum albumin (type CRG-7) was purchased from Armour Pharmaceutical (Kankakee, Ill, USA). Collagenase (type CLS) was from Worthington Biochemical (Freehold, NJ, USA). Silicone oil (density $0.99 \mathrm{~g} / \mathrm{ml}$ ) was purchased from A. H. Thomas (Philadelphia, Pa, USA). 2-deoxy-D-[1- $\left.{ }^{3} \mathrm{H}\right]$ glucose and $(-) \mathrm{N}^{6}-\left(3-\left[{ }^{125} \mathrm{I}\right]-\right.$-iodo-4-hydroxyphenylisopropyl) adenosine $\left({ }^{125} \mathrm{I}-\mathrm{HPIA}\right)$ were from Amersham Corporation (Arlington Heights, Ill, USA). Hepes (N-2-hydroxyelthylpiperazine- $\mathrm{N}^{1}$-2-ethanesulfonic acid), adenosine deaminase (type III), theophylline, 2-deoxy-D-glucose, phloretin, polyethylene glycol (PEG; molecular weight approx. 8,000 ) bovine gammaglobulin, and 3-[(3-cholamidopropyl)-dimethylammoniol $]-$ 1-propane-sulfonate (Chaps) were from Sigma Chemical Co. (St. Louis, Mo, USA). Unlabelled HPIA was from Boehringer Mannheim Biochemicals (Indianapolis, Ind, USA).

\section{Animal treatments}

Male Sprague-Dawley rats weighing $182 \pm 2 \mathrm{~g}$ (mean $\pm \mathrm{SEM}$ ) were randomized into groups of 6 . The animals were injected intraperitoneally with theophylline ( $30 \mathrm{mg} / \mathrm{kg}$, dissolved in $0.9 \% \mathrm{NaCl}$ ) each day at 11.00 hours. Control animals were injected with an equivalent volume of $0.9 \% \mathrm{NaCl}$. The treatment period was 7 days. At 09.00 hours on day 8 , the animals were killed by a blow to the head followed by cervical dislocation, and epididymal fat pads were removed. 


\section{Isolation of adipocytes}

Adipocytes were liberated from the epididymal fat pads by a modification of the method of Rodbell [13] as follows. The tissue was minced with scissors and then incubated at $37^{\circ}$ for $1 \mathrm{~h}$ in a buffer containing $137 \mathrm{mmol} / 1 \mathrm{NaCl}, 5 \mathrm{mmol} / 1 \mathrm{KCl}, 4.2 \mathrm{mmol} / 1 \mathrm{NaHCO} 3,1.3 \mathrm{mmol} / 1$ $\mathrm{CaCl}_{2}, 0.5 \mathrm{mmol} / 1 \mathrm{KH}_{2} \mathrm{PO}_{4}, 0.5 \mathrm{mmol} / 1 \mathrm{MgCl}_{2}, 0.4 \mathrm{mmol} / 1 \mathrm{MgSO}_{4}$, $5 \mathrm{mmol} / 1$ glucose, $20 \mathrm{mmol} / 1$ Hepes, $\mathrm{pH} 7.4$ plus bovine serum albu$\min (40 \mathrm{mg} / \mathrm{ml})$ and collagenase $(1.5 \mathrm{mg} / \mathrm{ml})$. The digested tissue was filtered through $1000 \mu \mathrm{m}$ nylon mesh, centrifuged $(25 \mathrm{~g}$ for $90 \mathrm{~s}$ ) and washed three times with the appropriate buffer for glucose transport or insulin binding studies (see below).

\section{Glucose transport assay}

Uptake of 2-deoxyglucose was used as an index of the rate of glucose transport [14]. Adipocytes (approximately 300,000 cells in $1 \mathrm{ml}$ ) were incubated with shaking for $45 \mathrm{~min}$ at $37^{\circ} \mathrm{C}$ in the same buffer as described above, except that the bovine serum albumin concentration was $10 \mathrm{mg} / \mathrm{ml}$ and there was no collagenase or glucose. Additions were as described in the text and figure legends.

At the end of the incubation period, 2-deoxy-D-[1-3 $\mathrm{H}]$-glucose (sp radioact $1.6 \mathrm{Ci} / \mathrm{mol}$ ) was added (final concentration $0.1 \mathrm{mmol} / \mathrm{l}$ ). The assays were terminated $3 \mathrm{~min}$ later by transferring $300 \mu \mathrm{l}$ samples of the cell suspension to plastic microtubes containing silicone oil $(50 \mu \mathrm{l})$. The tubes were centrifuged for $30 \mathrm{~s}$ in a Beckman Microfuge, and the assay was considered terminated when centrifugation began. The tubes were cut through the oil layer with a razor blade, and the radioactivity in the cell pellet was measured in a liquid scintillation counter. In each experiment, the amount of 2-deoxyglucose trapped non-specifically in the cell layer was determined by measuring uptake in the presence of $0.3 \mathrm{mmol} / 1$ phloretin, which completely inhibits glucose transport [15]. All data for 2-deoxyglucose uptake have been corrected by subtraction of this value.

\section{Insulin receptor assay}

Insulin was iodinated by the chloramine $\mathrm{T}$ method and purified on a column of Sephadex G-50 [16]. The specific activity of the iodinated insulin was approximately $150-180 \mu \mathrm{Ci} / \mu \mathrm{g}$.

Adipocytes were suspended in a buffer similar to that used for tissue digestion, except that the albumin concentration was $10 \mathrm{mg} / \mathrm{ml}$, the $\mathrm{pH}$ was 7.8 and there was no collagenase. Cells were incubated with ${ }^{125}$ I-insulin $(7.5 \mathrm{mU} / 1)$ plus various concentrations of unlabeled insulin for $2.5 \mathrm{~h}$ at $16^{\circ} \mathrm{C}$. Binding of ${ }^{125} \mathrm{I}$-insulin was determined as previously described $[8,17]$.

\section{Adenosine receptor assay}

Total cellular adenosine receptors were assayed on detergent-solubilized cell extracts using ${ }^{125} \mathrm{I}$-labeled hydroxyphenyl isopropyl adenosine $[18,19]$ as follows. Adipocytes suspended in the glucose transport buffer ( $1 \mathrm{ml}$, containing approximately 300,000 cells) were centrifuged ( $25 \mathrm{~g}$ for $90 \mathrm{~s}$ ) and the buffer was removed. The cells were then solubilized in $50 \mathrm{mmol} / 1$ Hepes, $0.15 \mathrm{~mol} / 1 \mathrm{NaCl}, 10 \mathrm{mmol} / 1 \mathrm{MgCl}_{2}, 0.5 \%$ Chaps, $\mathrm{pH} 7.6$ (volume equal to that of the packed cell volume) for $45 \mathrm{~min}$ at $37^{\circ}$. The cell suspension was mixed on a vortex mixer every 10 min during the solubilizing step. After solubilizing, the cell suspension was centrifuged for 5 min in a Beckman Microfuge, and the aqueous layer was separated from the triglyceride and insoluble precipitated material.

Adenosine receptors were assayed on $30 \mu 1$ samples of the soluble extract. The total assay volume was $70 \mu \mathrm{l}$ and contained, at final concentrations, $50 \mathrm{mmol} / 1$ Hepes, $\mathrm{pH} 7.6,10 \mathrm{mmol} / 1 \mathrm{MgC} 1_{2}, 0.15 \mathrm{~mol} / 1$ $\mathrm{NaCl}, 0.2 \mathrm{nmol} / \mathbf{l}^{125} \mathrm{I}$-HPIA (approx $0.03 \mu \mathrm{Ci} /$ assay) $10 \mu \mathrm{g} / \mathrm{ml}$ adenosine deaminase and $0-100 \mathrm{nmol} / \mathrm{l}$ unlabelled HPIA. The tubes were incubated for $2.5 \mathrm{~h}$ at $37^{\circ} \mathrm{C}$, and then the bound radioactivity was precipitated with polyethylene glycol as follows. Bovine gamma globulin solution $(20 \mu 1$ of $12.5 \mathrm{mg} / \mathrm{ml}$ in $50 \mathrm{mmol} / 1$ Hepes, $\mathrm{pH} 7.6)$ was added as carrier, followed by $500 \mu$ l of icecold $15 \%(\mathrm{w} / \mathrm{v})$ polyethylene glycol. The tubes were mixed thoroughly and then duplicate $200-\mu l$ samples were transferred to plastic $300 \mu \mathrm{l}$ microtubes containing $50 \mu \mathrm{l}$ of $15 \%$ polyethylene glycol. The tubes were centrifuged in a Beckman Microfuge for $3 \mathrm{~min}$. The tips of the microtubes, containing the precipitated material, were cut with a razor blade and transferred to $12 \times 75 \mathrm{~mm}$ polystyrene tubes for measurement of radioactivity in a gamma-counter. For each extract, non-specific binding was measured in the presence of a large excess of HPIA $(10 \mu \mathrm{mol} / \mathrm{l})$. Non-specific binding was approximately $5-10 \%$ of total binding $(0.5-1 \%$ of total radioactivity). All data have been corrected by subtraction of non-specific binding.

\section{DNA assays}

To allow for variations in cell concentration, all data have been normalized to DNA. DNA was assayed by a modification of the method of Burton [20] as follows. Triplicate $1 \mathrm{ml}$ samples of cell suspensions were extracted 3 times with $10 \%(\mathrm{w} / \mathrm{v}) \mathrm{HC}_{3}$. The extracts were pooled, and $2.3 \mathrm{ml}$ of $4 \%$ diphenylamine in glacial acetic acid, followed by $0.115 \mathrm{ml}$ of acetaldehyde solution $\left(1.6 \mathrm{mg} / \mathrm{ml}\right.$ in $\mathrm{H}_{2} \mathrm{O}$ ) were added. The tubes were incubated at $56{ }^{\circ} \mathrm{C}$ for $1 \mathrm{~h}$, cooled on ice and then extracted with $1.5 \mathrm{ml}$ amyl acetate. Standards containing $0-20 \mu \mathrm{g}$ DNA were run in parallel. The optical densities of the organic phase were measured at $595 \mathrm{~nm}$.

\section{Statistical analysis}

All data were analyzed by Student's t test. Values of $p<0.05$ were judged statistically significant. Levels of significance are given in the figure legends.

Table 1. Effect of theophylline treatment on total weight gain and epididymal adipose tissue weight

\begin{tabular}{lll}
\hline & $\begin{array}{l}\text { Body weight } \\
(\mathrm{g})\end{array}$ & $\begin{array}{l}\text { Fat pad weight } \\
(\mathrm{g})\end{array}$ \\
\hline Control & $229 \pm 6$ & $2.12 \pm 0.12$ \\
Theophylline-treated & $216 \pm 6$ & $1.97 \pm 0.13$ \\
$p$ & $\mathrm{NS}$ & $\mathrm{NS}$ \\
\hline
\end{tabular}

Values are mean \pm SEM for 6 control and 6 theophylline-treated rats. $\mathrm{NS}=$ not significant $(p>0.1)$

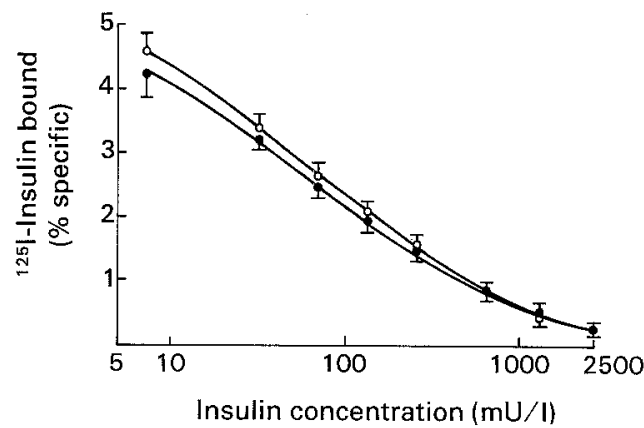

Fig. 1. Insulin binding to adipocytes from control and theophyllinetreated rats. Adipocytes from control (-) and theophyllinetreated $(\mathrm{O}-\mathrm{O})$ rats were incubated with ${ }^{125} \mathrm{I}$-insulin $(7.5 \mathrm{mU} / \mathrm{l})$ plus unlabeled insulin as indicated for $2.5 \mathrm{~h}$ at $16^{\circ} \mathrm{C}$. ${ }^{125} \mathrm{I}$-insulin binding was determined as described in the Methods section. Results are mean $\pm \operatorname{SEM}(n=6)$ and are expressed per microgramme DNA None of the differences between the control and treated groups are significant 


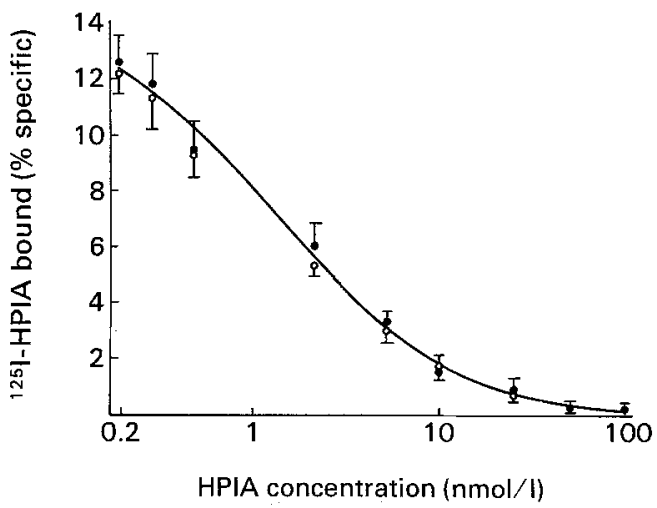

Fig. 2. Effect of theophylline treatment on adipocyte adenosine receptors. Adipocytes from control $(-$ ) and theophylline-treated $(\mathrm{O}-\mathrm{O})$ rats were solubilized and assayed for adenosine receptors using $0.2 \mathrm{nmol} / \mathbf{1}^{125} \mathrm{I}$-HPIA and unlabeled HPIA as indicated $(n=6)$. See Methods section for details

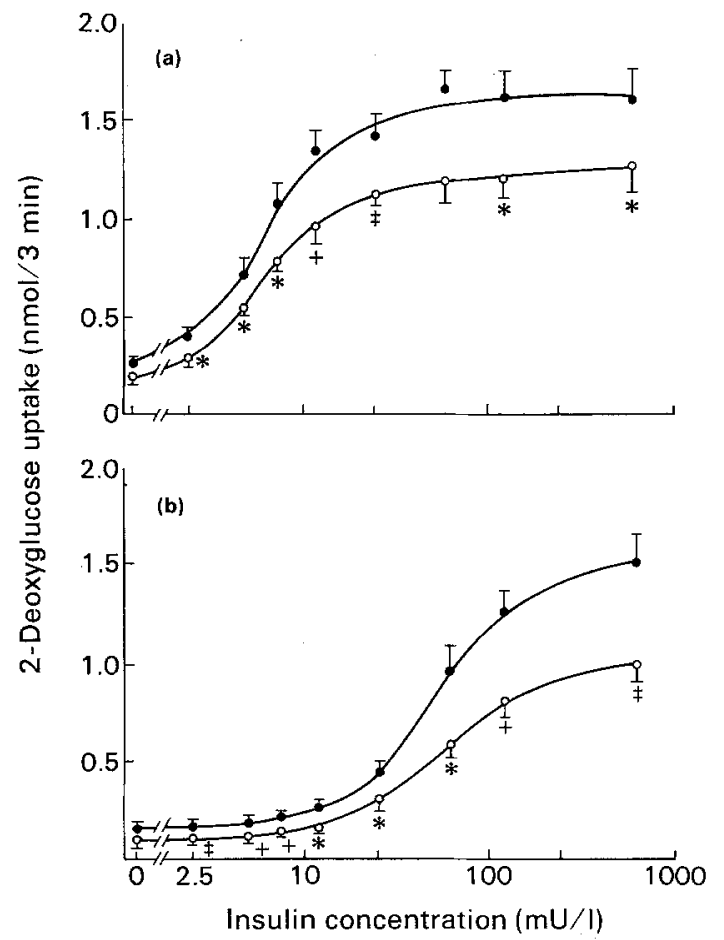

Fig.3. Glucose transport in adipocytes from control and theophylline-treated rats. Adipocytes from control ( - ) and theophyllinetreated $(\mathrm{O}-\mathrm{O})$ rats were incubated with insulin as indicated either without (panel a) or with (panel b) adenosine deaminase $(10 \mu \mathrm{g} / \mathrm{ml}$ ) for $45 \mathrm{~min}$ at $37^{\circ}$. Glucose transport (2-deoxyglucose uptake) was then measured over a 3-min period as described in Methods. Results are means \pm SEM of six experiments performed on different days, each experiment consisting of a complete dose-response curve on one control and one treated animal $(n=6)$. The data are expressed per $\mu \mathrm{g}$ DNA. Values significantly different from controls are indicated by $*$, $p<0.05 ;+, p<0.02 ; \neq, p<0.01$

\section{Results}

\section{Effect of theophylline on weight gain and fat pad size}

The data in Table 1 demonstrate that administration of theophylline for 7 days had no significant effect on ei- ther total body weight or weight of the epididymal fat pads.

\section{Insulin receptors}

Competition curves of ${ }^{125}$ I-insulin binding to adipocytes isolated from control and theophylline-treated rats are shown in Figure 1. The curves are almost identical for the two groups of rats, indicating that theophylline treatment did not significantly alter insulin receptors.

\section{Adenosine receptors}

Figure 2 shows competition curves of ${ }^{125}$ I-hydroxyphenylisoprophyl adenosine binding to detergent-solubilized extracts of adipocytes from control and theophylline-treated rats. This radioactive ligand is known to bind specifically to the $\mathrm{A}_{1}$ adenosine receptor (see Discussion). In contrast to its effect on brain [21, 22], theophylline did not cause an increase in the number of adenosine receptors in adipocytes, as evidenced by the almost superimposable competition curves (Figure 2).

\section{Glucose transport}

Glucose transport (2-deoxyglucose uptake) rates in the presence of $0-625 \mathrm{mU} / 1$ insulin, in adipocytes from control and theophylline-treated rats, are shown in Figure 3 . Since adipocytes spontaneously release adenosine $[5,6]$, measurements were performed both in the absence and presence of adenosine deaminase to determine whether any observed effects were due to differences in factors such as adenosine release.

Figure $3 \mathrm{a}$ shows glucose transport in the absence of adenosine deaminase. It is clear that the glucose transport rate is lower in the adipocytes from theophyllinetreated rats than in cells from untreated animals. This decreased rate is apparent at each insulin concentration including the basal (although the latter was not statistically significant). Furthermore, the magnitude of the difference is approximately equal at each insulin concentration; transport rates in the cells from treated rats are approximately $25 \%$ lower than in controls.

The half-maximally effective concentration of insulin was calculated from the insulin dose-response curve of each individual rat. This value was not altered in the theophylline-treated animals as compared to controls ( $6.7 \pm 0.5 \mathrm{mU} / 1$ and $6.5 \pm 0.5 \mathrm{mU} / 1$ respectively).

As in the absence of adenosine deaminase (above), the glucose transport rate was lower in the cells from theophylline-treated rats when measured in the presence of the enzyme (Fig. $3 \mathrm{~b}$ ). Adenosine deaminase caused a marked shift to the right in the insulin dose-response curve for glucose transport, as we have previously reported $[7,8]$. However, there was again no difference in the $\mathrm{EC}_{50}$ for insulin in the cells from control and treated rats $(52 \pm 7 \mathrm{mU} / 1$ and $52 \pm 5 \mathrm{mU} / 1$ respectively). 
Since the decreased glucose transport rate in adipocytes from theophylline-treated rats is evident both in the absence and in the presence of adenosine deaminase, these findings suggest that the lowered transport rate is intrinsic to the cells, rather than being due to differences in adenosine release in vitro.

\section{Discussion}

The findings demonstrate that a 7-day administration of theophylline to rats caused decreased glucose transport rates in adipocytes at all insulin concentrations. The basal rate was also decreased, although this was not statistically significant. Theophylline did not alter the halfmaximally effective concentration of insulin, and insulin binding was unaltered. We therefore conclude that the decreased transport rate is due to a post-insulin binding defect. The insulin receptor possesses a tyrosine-specific protein kinase activity which has been proposed to be involved in insulin action [23,24]. It is possible that theophylline alters the activity of this kinase, and so it is not clear whether the findings are due to a true post-receptor defect. However, since the responsiveness of the cells to insulin was decreased, rather than the insulin sensitivity, it is more likely that the insulin resistance is due to a decrease in total glucose transporters.

It is believed that the in vivo effects of methyl xanthines are mediated via inhibition of adenosine receptors [1, 2]. These adenosine receptors can be sub-divided into 2 classes: $\mathrm{A}_{1}$ receptors are usually inhibitory to adenylate cyclase, while $A_{2}$ receptors are usually stimulatory $[25,26]$. Rat adipocytes possess primarily $A_{1}$ receptors. Theophylline is equally potent at $\mathrm{A}_{1}$ and $\mathrm{A}_{2}$ receptors, with $\mathrm{IC}_{50}$ values in the range of $5-40 \mu \mathrm{mol} / \mathrm{l}$ [27]. Therefore, the current findings suggest that chronic blockade of adipocyte adenosine receptors leads to decreased glucose transport rates, and hence that adenosine chronically increases glucose transport rates in adipose tissue. Adenosine is known to be a potent inhibitor of adipocyte lipolysis [5, 11]; increases the sensitivity of these cells to effects of insulin on glucose transport [7, 8], glucose oxidation and lipolysis [9]; and blocks certain actions of catecholamines [28] and glucagon [7]. The current findings suggest a further role for adenosine in regulation of adipocyte metabolism, i.e. the chronic maintenance of glucose transport rates.

As outlined above, it is probable that the mechanism by which theophylline administration decreases glucose transport rates is related to antagonism of adenosine action. The exact mechanism by which this occurs is not clear, since the acute response to adenosine is increased insulin sensitivity, rather than responsiveness. However, these two effects may be related, since chronic hypoinsulinaemia causes decreased responsiveness of glucose transport to insulin [29] while chronic hyperinsulinaemia has the opposite effect [30]. Thus, it is possible that blocking adenosine receptors chronically decreases the sensitivity of adipocytes to insulin, creating a situation similar to chronic hypoinsulinaemia.

An alternative explanation for the findings is that the effects of theophylline are due to chronic elevation of cyclic AMP levels. Adenosine inhibits adenylate cyclase in adipocytes $[4,25,26]$. Therefore, chronic theophylline treatment would be expected to increase adipocyte cyclic AMP. Indeed, the most easily demonstrated effect of methyl xanthines in vivo is increased plasma free fatty acid concentrations [31], probably secondary to lipolysis and hence cyclic AMP in adipose tissue. The conclusion that this effect is due to blockade of adenosine receptors is evidenced by the finding that the order of potency among several methyl xanthines exactly parallels their order of potency as adenosine receptor antagonists [31]. There was no relation to their potency as phosphodiestase inhibitors.

Using protocols similar to that in the current study, Fredholm [21] and Murray [22] demonstrated up-regulation of adenosine receptors in brain following caffeine or theophylline treatment. We found no change in adipocyte adenosine receptors. Similarly, Fredholm [21] demonstrated that the inhibitory effect of $\mathrm{N}^{6}$-phenylisopropyl adenosine on adipocyte lipolysis was not potentiated following chronic caffeine administration, although the number of receptors in the brain was increased by $25-30 \%$. Thus, it appears that adipocyte adenosine receptors differ from the brain receptors in that they do not up-regulate in response to methyl xanthines.

Evidence is presented that adenosine can chronically increase the insulin responsiveness of adipose tissue, at a post-insulin binding level. This may be relevant to conditions such as obesity and Type 2 diabetes, which are associated with post-insulin receptor defects in insulin action [32, 33]. There is evidence that changes in adenosine are involved in the insulin resistance of adipose tissue in obesity. Firstly, adipose tissue from obese mice has a decreased activity of $5^{\prime}$ nucleotidase (an enzyme involved in adenosine production) but increased activities of adenosine deaminase and adenosine kinase (which metabolize adenosine) as compared to lean controls [12]. This suggests that adipose tissue adenosine concentrations are low in obesity. Secondly, it has been demonstrated that lipolysis in adipocytes from obese human subjects is less sensitive to inhibition by $\mathrm{N}^{6}$-phenylisopropyl adenosine than in cells from lean individuals [34], suggesting adenosine receptor number or affinity may be decreased in obesity. Thus, a rationale for treatment of these conditions may be to develop agents which increase tissue adenosine or adenosine receptor concentrations. However, it should be pointed out that adenosine acutely decreases the insulin sensitivity of skeletal muscle [35]. This tissue difference may be due to a predominance of $\mathrm{A}_{2}$ receptors in muscle, as compared to $A_{1}$ receptors in adipose tissue. Thus, it is likely that tissue-specific, or receptor-specific, agents 
would have to be developed for such an approach to be effective in the treatment of insulin resistance.

Acknowledgements. I thank Ms. M. Partin for excellent technical assistance and Ms. L. Bramer for preparation of the manuscript. I am grateful to Dr. M.J.Prince and Dr. C.A.Stuart for providing me with ${ }^{125}$ I-labelled insulin and for critically reviewing the manuscript. This work was supported by a New Investigator Research Award (DK 36719 ) from the National Institutes of Health.

\section{References}

1. Fredholm BB (1980) Are the effects of methyl xanthines due to antagonism of endogenous adenosine? Trends Pharm Sci 1: 129-132

2. Fredholm BB (1985) On the mechanism of action of theophylline and caffeine. Acta Med Scand 217: 149-153

3. Arch JRS, Newsholme EA (1979) The control of the metabolism and the hormonal role of adenosine. Essays Biochem 14: 82-123

4. Schwabe U, Ebert R, Erbler HC (1975) Adenosine release from fat cells: effects on cyclic AMP levels and hormone action. Adv $\mathrm{Cy}-$ clic Nucleotide Res 5: 569-584

5. Schwabe U, Ebert R, Erbler HC (1973) Adenosine release from isolated fat cells and its significance for the effects of hormones on cyclic 3', 5'-AMP levels and lipolysis. Naunyn-Schmiedeberg's Arch Pharmacol 276: 133-148

6. Kather H, Wieland E, Fischer B, Wirth A, Schlierf G (1985) Adrenergic regulation of lipolysis in abdominal adipocytes of obese subjects during caloric restriction: reversal of catecholamine action caused by relief of endogenous inhibition. Eur J Clin Invest 15: $30-37$

7. Green A (1983) Glucagon inhibition of insulin-stimulated 2-deoxyglucose uptake by rat adipocytes in the presence of adenosine deaminase. Biochem J 212: 189-195

8. Green A, Bustillos DP, Misbin RI (1984) Beta-hydroxybutyrate increases the insulin sensitivity of adipocyte glucose transport at a postreceptor level. Diabetes 33: 1045-1050

9. Schwabe U, Schönhöfer PS, Ebert R (1974) Facilitation by adenosine of the action of insulin on the accumulation of adenosine $3^{r}$ : $5^{\prime}$-monophosphate, lipolysis and glucose oxidation in isolated fat cells. Eur J Biochem 46: 537-545

10. Fain JN, Wieser PB (1975) Effects of adenosine deaminase on cyclic adenosine monophosphate accumulation, lipolysis and glucose metabolism of fat cells. J Biol Chem 250: 1027-1034

11. Kather H, Bieger W, Michel G, Aktories K, Jakobs KH (1985) Human fat cell lipolysis is primarily regulated by inhibitory modulators acting through distinct mechanisms. J Clin Invest 76 : $1559-1565$

12. Green A,Fisher M, Newsholme EA (1981) Maximum activities of enzymes involved in adenosine metabolism in adipose tissue of rats and mice under conditions of variation in insulin sensitivity. Biochim Biophys Acta 676: 125-128

13. Rodbell M (1964) Metabolism of isolated fat cells I: Effects of hormones on glucose metabolism and lipolysis. J Biol Chem 239: $375-380$

14. Olefsky JM (1978) Mechanisms of the ability of insulin to activate the glucose-transport system in rat adipocytes. Biochem $\mathbf{J} 172$ : 137-145

15. Gliemann J (1985) Glucose transport and metabolism in the adipocyte: In: Larner J, Pohl SL (eds) Methods in diabetes research, Vol I, Part C. John Wiley, New York, pp 105-118

16. Freychet P, Roth J, Neville DM Jr (1971) Monoiodoinsulin: demonstration of its biological activity and binding to fat cells and liver membranes. Biochem Biophys Res Commun 43: 400-408

17. Marshall S, Green A, Olefsky JM (1981) Evidence for recycling of insulin receptors in isolated rat adipocytes. J Biol Chem 256: 11464-11470
18. Schwabe U, Lenschow V, Ukena D, Ferry DR, Glossmann $H$ (1982) $\left.{ }^{[25} \mathrm{I}\right] \mathrm{N}^{6}$-p-hydroxyphenylisopropyladenosine, a new ligand for Ri adenosine receptors. Naunyn-Schmiedeberg's Arch Pharmacol 321: 84-87

19. Linden J (1984) Purification and characterization of (-) $\left[{ }^{125} \mathrm{~T}\right]$ hydroxyphenylisopropyladenosine, an adenosine R-site agonist radioligand and the theoretical analysis of mixed sterioisomer radioligand binding. Mol Pharmacol 26: 414-423

20. Burton K (1956) A study of the conditions and mechanism of the diphenylamine reaction for the colorimetric estimation of deoxyribonucleic acid. Biochem $\mathrm{J}$ 62: 315-323

21. Fredholm BB (1982) Adenosine actions and adenosine receptors after 1 week treatment with caffeine. Acta Physiol Scand 115: 283-286

22. Murray TF (1982) Up-regulation of rat cortical adenosine receptors following chronic administration of theophylline. Eur J Pharmacol 82: 113-114

23. Kasuga M, Karlsson FA, Kahn CR (1982) Insulin stimulates the phosphorylation of the 95,000 -dalton subunit of its own receptor. Science 215: 185-187

24. Kahn CR, White MF, Grigorescu F, Takayama S, Häring HU, Crettaz M (1985) The insulin receptor protein kinase. In: Czech MP (ed) Molecular basis of insulin action. Plenum Press, New York, pp 67-93

25. Wolff J, Londos C, Cooper DM (1981) Adenosine receptors and the regulation of adenylate cyclase. Adv Cyclic Nucleotide Res 14: 199-214

26. Daly JW (1983) Adenosine receptors: characterization with radioactive ligands. In: Daly JW, Kuroda Y, Phillis JW, Shimizu H, Ui M (eds) Physiology and pharmacology of adenosine derivatives. Raven, New York, pp 59-69

27. Fredholm BB (1984) Cardiovascular and renal actions of methyl xanthines. Prog Clin Biol Res 158: 303-330

28. Green A (1983) Catecholamines inhibit insulin-stimulated glucose transport in adipocytes, in the presence of adenosine deaminase. FEBS Lett 152: 261-264

29. Kobayashi M, Olefsky JM (1979) Effects of streptozotocin-induced diabetes on insulin binding, glucose transport and intracellular glucose metabolism in isolated rat adipocytes. Diabetes 28: $87-95$

30. Kobayashi M, Olefsky JM (1978) Long-term regulation of adipocyte glucose transport capacity by circulating insulin in rats. J Clin Invest 62: 73-81

31. Fredholm BB (1984) Gastrointestinal and metabolic effects of methylxanthines. Prog Clin Biol Res 158: 331-354

32. Olefsky JM, Kolterman OG, Scarlett JA (1982) Insulin action and resistance in obesity and noninsulin-dependent type II diabetes mellitus. Am J Physiol 243: E15-E30

33. Kolterman OG, Insel J, Saekow M, Olefsky JM (1980) Mechanisms of insulin resistance in human obesity: evidence for receptor and postreceptor defects. J Clin Invest 65: 1272-1284

34. Ohisalo JJ, Ranta S, Huhtaniemi IT (1986) Attenuated adenosine $R$-site effect in adipocytes in obesity. Metabolism 35: 143-46

35. Budohoski L, Challiss RA, McManus B, Newsholme EA (1984) Effects of analogues of adenosine and methyl xanthines on insulin sensitivity in soleus muscle of the rat. FEBS Lett 167:1-4

Received: 17 September 1986

and in revised form: 20 January 1987

Dr. Allan Green

Department of Internal Medicine

Endocrinology - Metabolism

OJSH Room 4.174 Route E68

University of Texas Medical Branch

Galveston, TX 77550, USA 